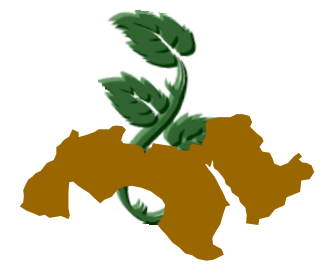

Arab Univ. J. Agric. Sci., Ain Shams Univ., Cairo, 23(1), 37 - 49, 2015

\title{
WHEATGRASS JUICE AND ITS NUTRITIONAL VALUE AS AFFECTED BY SPROUTING CONDITION
}

\author{
Dina A. Anwar²; A. Abou El-Yazied'; Thanaa, F. Mohammadi² \\ and M.M.F. Abdallah ${ }^{1}$ \\ 1. Horticulture Department, Faculty of Agriculture, Ain Shams University, Cairo, Egypt \\ 2. Regional Center for Food and Feed, Agri. Res. Center, Giza, Egypt
}

Keywords: Wheatgrass juice, Nutritive value, Sprouting, Chlorophyll, Sprouting condition

\begin{abstract}
Wheatgrass juice is the young grass of the common wheat plant (Triticum aestivum) freshly juiced for human consumption. The objective of the investigation performed was to assess the nutritional value of wheatgrass juice under laboratory and open field conditions at two different cuts. Protein, chlorophyll contents, minerals content $(\mathrm{Ca}$, $\mathrm{Fe}, \mathrm{Mg}, \mathrm{Zn}$ and Se) and amino acids content as well as phytochemical constituents were determined. Grown wheatgrass at laboratory caused an increase of the protein content of its juice over open field condition. High chlorophyll content was observed under open field especially at second cut. Most of minerals content underwent to increase under open field except Mg content. Aspartic acid was recorded the highest amino acid in both laboratory and open field. Total essential amino acids were increased under open field condition at both first and second cut followed by first cut at laboratory. No big changes of natural phytochemicals constituents can shown between laboratory and open field condition while it was more pronounced compare with wheat seeds. The study suggested that sprouting wheat seeds at laboratory and open field improve the nutritional value of grass juice with preferably to laboratory condition especially at first cut and for saving agricultural land.
\end{abstract}

\section{INTRODUCTION}

Wheatgrass juice (WGJ) is an extract squeezed from the mature sprouts of wheat seeds
(Triticum aestivum). Wheatgrass, young grass of common wheat plant, is freshly juiced or dried into powder for animal and human consumption - both the forms provide chlorophyll, minerals $\mathrm{K}, \mathrm{Ca}, \mathrm{Fe}$, $\mathrm{Mg}, \mathrm{Na}$ and $\mathrm{S}$, vitamins such as $\mathrm{A}, \mathrm{B}, \mathrm{C}$ and $\mathrm{E}$, enzymes and 17 forms of amino acids(Singh et al 2012). Germination is a natural process occurred during growth period of seeds in which they meet the minimum condition for growth and development (Sangronis et al 2006). During soaking and germination for producing sprouts, seeds loss dry matter. Chavan and Kadam (1989) stated that the original dry weight of the seeds decreased during soaking and subsequent sprouting process due to leaching of materials and oxidation of substances from the seeds. Chung et al (1989) measured $9.4 \%$ decreased in dry matter of sprouted barley seeds over 5 days, while Abdallah et al (2014) found $14.8 \%$ loss for 7 days. During this period the chemical composition changes drastically because biochemical activity produces essential compounds and energy (Moongngarm and Saetung (2010). Wheatgrass can be traced back in history over 5000 years, to ancient Egyptian and perhaps even early Mesopotamian civilizations. It is purported that ancient Egyptians found sacred the young leafy blades of wheat and prized them for their positive effect on their health and vitality. Wheatgrass can extracts for consume by two different types like squeezed or chewed then throw out. Wheatgrass has quickly become "the new age espresso" offered in smoothies and juices, salads, and even in powders and tablets and is one of the cereal grasses mostly used as a health drink (BenArye et al 2002). Wheatgrass juice will provide you with more energy by fulfilling nutritional deficiencies and by removing wastes that clog your cells, blood, tissues and organs (Mujoriya and Ba- 
buBodla, 2011). Wheatgrass is a complete food that contains bioflavonoids, proteins and other important nutrients and helps in maintaining body functions (Mogra and Rathi, 2013).A very few publications are reported in scientific literature on nutritive and antioxidant properties of wheat sprout extracts where it is reported that these extracts inhibit the DNA oxidative damage and effective in suppressing superoxide radical that can further lead to various diseases (Falcioni et al 2002). At present, the wheatgrass is available in the form of products such as healthy diets (powders, tablets) in USA, East Asian countries and Eastern Europe; however, it's not popular in Egypt and lack knowledge about growing conditions for good quality of wheatgrass.

To solve these problems and to make wheatgrass juice widely consumed, this research work has been carried out. Thus, the main objectives of the study were: (1) growing wheatgrass under different condition and their effect of its quality (2) evaluate the nutritional value of formed grass juice.

\section{MATERIALS AND METHODS}

\section{Materials}

Grains of wheat were obtained from Field Crop Research Institute, Agricultural Research Center. Rice and wheat straw have been collected from a private farm located in Sharkia Governorate. Wheat and rice straw were sun dried and chopped $(2-4 \mathrm{~cm})$ according to Mohammadi and Abdallah (2007).

\section{Wheat sprout production methods}

Production method for wheat grains sprout was tray method as described by Abdallah (2008) using about $250 \mathrm{gm}$ of rice or wheat straw on the bottom as sprouting media. The plastic tray size was $(40 \times 24 \times 11 \mathrm{~cm})$. Grains of wheat were cleaned, washed and soaked in tap water placed in $0.7 \mathrm{~L}$. capacity glass jars for each replicate. The soaked period was $12 \mathrm{hr}$. (over night) to allow for initial germination before spread evenly on the wheat or rice straw medium as described by Mohammadi and Abdallah (2007). Wheat shoots were harvested after 8 days from grain sowing. The harvested shoot yield per unit area $\left(\mathrm{m}^{2}\right)$ and per unit volume of seeds $(\mathrm{kg})$ was calculated. Ten sprouts were randomizaly were chosen from each tray for sprout characters measurements.

\section{Experimental trials}

Many tray experiments were conducted in organic vegetable sprouts experimental laboratory in Horticulture Department, Faculty of Agriculture Ain shams University during 2013-2014. From the growing media experiment (data not shown), rice straw media recorded the highest yield and wheat sprout characters. Therefore, it was selected as a medium from the following experiments. In seeding density experiments, four densities were studied (155.6, 116.7, 77.8, $38.9 \mathrm{~g} /$ tray). The $116.7 \mathrm{gm}$ were selected for its best yield and shoot characters (data not shown).

\section{Open field versus laboratory sprout produc- tion}

Recommended rice straw medium with seeding density were used in laboratory to study number of shoot cuts and its juice production compared to open field wheat shoot production on one square meter plot area (clay soils) located in the vegetable experimental farm of the Faculty Agriculture, Ain shams university using seeding rates about 162 gm of dry grains per square meter in ten rows (one meter length). Shoots were harvested twice, the first cut when shoot length were more than $10 \mathrm{~cm}$ height (when shoots develop a split as another leaf emerges). The shoots of second cut were harvested when shoots reached about $10 \mathrm{~cm}$ height. Shoot characters in each cut and its juice volume and nutrition value were measured.

\section{Nutrient composition of wheatgrass juice}

Collected wheatgrass juice from first and second cuts after squeezed (either under laboratory or open field condition) were placed in a container for cold storage (in a common refrigerator or freezer) during analysis period. The major chemical constituents that make wheatgrass a valuable food such as protein according to AOAC (2012 a). Total chlorophyll according to Lichenthaler and Wellburn (1983), amino acids according to AOAC (2012b), minerals according to AOAC (2012c), phytochemicals constituent according to Santana et al (2013) were analyzed.

\section{Statistical analysis}

The production data were statistically analyzed by analysis of variance using completely randomized design and least significant difference (L.S.D) 
at 0.05 levels according to the method described by Snedecor and Cochran (1980).

\section{RESULT AND DISCUSSION}

\section{Effect of open field versus laboratory pro- duction on wheat grass sprout characters}

As a result of growing locations, it could be noticed that daily wheatgrass shoot height was significantly increased when produced grasses under laboratory condition in compare with open field condition (Table, 1 ) shoot weight $(\mathrm{mg})$ per day was increased sharply under open field condition (11 $\mathrm{mg}$ ) over laboratory (5.0 mg).

These result may be due to that low light (indirect sun light) under laboratory condition with resulted in etiolated growth and increased shoot height and may reduced seedling dry weight and that can be reflect to fresh seedling weight adverse to open field. The increase in shoot weight would be brought significant increase in fresh yield of shoots $(\mathrm{kg} / \mathrm{kg}$ of seeds) or growing grass in open field not only increase shoot weight but also it caused an increase in fresh yield of wheatgrass shoots $(\mathrm{kg} / \mathrm{kg}$ of seeds). Conversely, higher yield of fresh shoots $(\mathrm{g} / \mathrm{m} 2 /$ day) was recorded at laboratory which reached $(372.9 \mathrm{~g})$ in compare with open field $(24.53 \mathrm{~g})$. This increment may be related to the differ of sowing method between laboratory and open field. While it was in rows at open field, it was sprinkled in trays at laboratory and this can decline the growing area per square meter at open field compare with laboratory ( 5 times increased in area) in addition to higher seeding density in laboratory (37.5 bold).

According to Schnabel's research on wheatgrass grown outdoors, the environment in which wheatgrass grows affects its vitality. The wheatgrass sown through the winter and harvested at the jointing stage has maximum concentration of active principles. At this stage the plant reaches its peak nutritional value; after jointing, concentrations of chlorophyll, protein, and vitamins decline sharply. Thus wheatgrass is harvested just prior to this jointing stage, when the tender shoots are at their peak of nutritional potency. Wheatgrass grown outdoors is harvested, dehydrated at a low temperature and sold in tablet and powdered concentrates. Growing wheatgrass indoors usually requires the grass to be grown in small trays with the wheat grains close together for a high yield (Singh et al 2012).
Quality and quantity of fresh wheatgrass juice and its residues per square meter also affected by growing locations (Table 2). At laboratory, the growth of wheatgrass in square meter by added five trays vertically, volume of juice and residues weight were built up under laboratory and the increment reached 1688 and $1855 \%$, respectively. However, no significant effect in juice $(\mathrm{ml})$ and residues weight $\mathrm{g} / \mathrm{kg}$ of seeds/day between laboratory and open field was observed over open field. Concerning cutting effect, first wheatgrass cut was an efficient growth which was the highest in all shoot characters in addition to volume juice and their residue. This result can be expected because seeds were exhausted most of its storage materials at primary growth (first cut). For about interaction between growing locations and number of cutting (Tables 1 and 2) there is no significant variation in shoot height and juice's residues weight (per square meter and $\mathrm{kg}$ of seeds). However, higher shoot weight $(\mathrm{mg})$ was recorded under field condition at first cut.

Fresh shoot yield ( $\mathrm{g} / \mathrm{kg}$ of seeds/day) and grass juice $(\mathrm{ml} / \mathrm{kg}$ of seeds/day) were increased at first cut under field condition but it is not significantly differ with first cut under laboratory condition. Nevertheless, fresh shoot yield per square meter and their juice were raised under laboratory over open field condition Tables ( 1 and 2 ). Variation in growth could be seen with changing conditions and environmental parameters were considered important for the growth of wheatgrass namely temperature, humidity, air circulation and time taken to reach a target height (Ashish et al 2012). Finally, wheatgrass was successfully grown under laboratory for its highly fresh wheatgrass yield in addition this production method can saving use of land and irrigation water. Concerning cutting effect, first grass cut was an efficient growth which was the highest in all shoots character in addition to volume of juice and their residues. This results can be expected because seeds were exhausted most of its storage materials at primary growth (first cut).

\section{Effect of sprouting on wheatgrass seedlings weight and development}

Soaking of seeds for $12 \mathrm{hr}$. enhanced fresh weight of dry seeds by $68 \%$ (Fig. 1). During growth of wheatgrass under non nutritional water culture, fresh seedling weight was increased in linear curve with growing days to be at the highest value after 
Table 1. Effect of growing locations and number of cutting and their interaction on wheatgrass yield

\begin{tabular}{|c|c|c|c|c|c|}
\hline \multicolumn{2}{|c|}{ Characters } & \multirow{2}{*}{$\begin{array}{c}\text { Shoot height } \\
\mathrm{cm} / \text { day }\end{array}$} & \multirow{2}{*}{$\begin{array}{c}\text { Shoot weight } \\
\text { mg/day }\end{array}$} & \multirow{2}{*}{$\begin{array}{c}\text { Fresh shoots } \\
\text { weight } \\
\text { g/m2/day }\end{array}$} & \multirow{2}{*}{$\begin{array}{c}\text { Fresh shoots } \\
\text { weight } \mathrm{g} / \mathrm{kg} \text { of } \\
\text { seeds/day }\end{array}$} \\
\hline Location (L) & Cutting (c) & & & & \\
\hline \multirow[t]{3}{*}{ Laboratory } & First cut & 1.38 & 6.0 & 565.7 & 93.22 \\
\hline & $\begin{array}{c}\text { Second } \\
\text { cut }\end{array}$ & 0.52 & 3.0 & 180.1 & 29.64 \\
\hline & Mean & 0.95 & 5.0 & 372.9 & 61.43 \\
\hline \multirow[t]{3}{*}{ Open field } & First cut & 0.77 & 14.0 & 33.23 & 102.5 \\
\hline & $\begin{array}{c}\text { Second } \\
\text { cut }\end{array}$ & 0.57 & 7.0 & 15.82 & 48.77 \\
\hline & Mean & 0.67 & 11.0 & 24.53 & 75.64 \\
\hline \multirow[t]{2}{*}{ Mean } & First cut & 1.08 & 10.0 & 299.5 & 97.86 \\
\hline & $\begin{array}{c}\text { Second } \\
\text { cut }\end{array}$ & 0.54 & 5.0 & 97.96 & 39.21 \\
\hline \multirow{3}{*}{ L.S.D (0.05) } & $\mathbf{L}$ & 0.025 & 0.33 & 19.113 & 4.154 \\
\hline & C & 0.025 & 0.33 & 19.113 & 4.154 \\
\hline & $L \times C$ & NS & 3.74 & NS & 14.70 \\
\hline
\end{tabular}

${ }^{*} m^{2}=5$ roof in lab exp. Only

Table 2. Effect of growing locations and number of cutting and their interaction on wheatgrass juice and residues

\begin{tabular}{|c|c|c|c|c|c|}
\hline \multicolumn{2}{|c|}{ Characters } & \multicolumn{2}{|c|}{ Juice $(\mathrm{ml}) /$ day $^{\star *}$} & \multicolumn{2}{|c|}{$\begin{array}{l}\text { Residues fresh weight } \\
\text { (g)/day }\end{array}$} \\
\hline Location (I) & Cutting (c) & $\mathrm{m}^{2^{*}}$ & kg of seeds & $\mathrm{m}^{2 *}$ & $\mathrm{~kg}$ of seeds \\
\hline \multirow{2}{*}{ Laboratory } & First cut & 249.7 & 41.1 & 226.2 & 37.21 \\
\hline & Second cut & 79.2 & 13.1 & 71.47 & 11.76 \\
\hline \multirow{4}{*}{ Open field } & Mean & 164.5 & 27.1 & 148.8 & 24.49 \\
\hline & First cut & 15.1 & 46.6 & 8.451 & 26.05 \\
\hline & Second cut & 3.4 & 10.3 & 6.774 & 20.89 \\
\hline & Mean & 9.3 & 28.45 & 7.613 & 23.47 \\
\hline \multirow{2}{*}{ Mean } & First cut & 132.4 & 43.9 & 117.3 & 31.63 \\
\hline & Second cut & 41.3 & 11.7 & 39.12 & 16.33 \\
\hline \multirow{3}{*}{ L.S.D (0.05) } & $\mathbf{L}$ & 8.48 & NS & 7.999 & NS \\
\hline & C & 8.48 & 1.996 & 7.999 & 1.612 \\
\hline & $L \times C$ & 237.86 & 12.416 & NS & NS \\
\hline
\end{tabular}

${ }^{*} m^{2}=5$ roof in lab exp. Only

**Juice $\mathrm{ml} / \mathrm{kg}$ shoots (F.W.) 


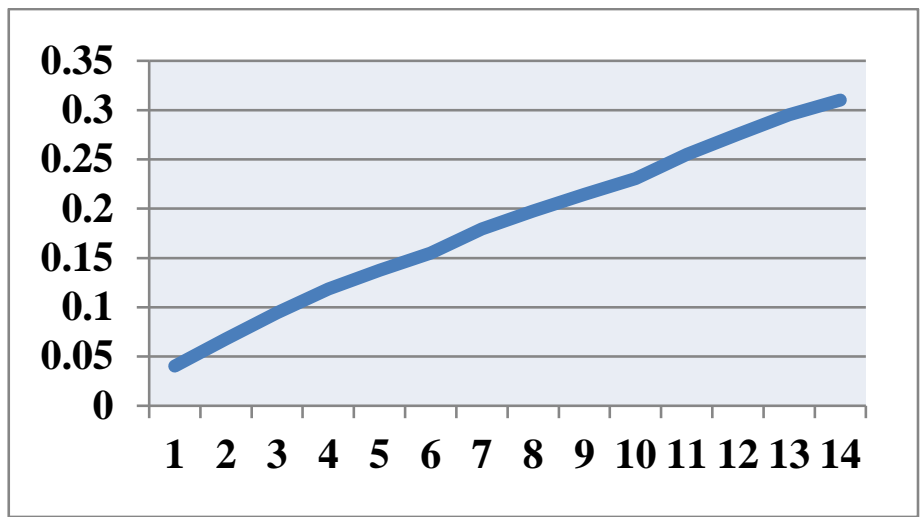

Fig. 1. Fresh seedling weight (gm)

twelve-sprouting days old (study period).From observed data, it was revealed that spread increment of fresh seedlings weight initiated with the first stages of seedling development followed by small increase until twelve days old. Increase in fresh weight denoted the growth (continuously increase of shoots and roots).

Depression in dry seedling weight was observed during growth of wheatgrass seedling started with first to twelfth days old of sprouting (Fig. 2). As growth of seedlings goes up, decrement in dry weight would be increase and this result would be expressed as the percentage of loss in dry weight (Fig. 3). After soaking seeds, $1 \%$ of dry seedling weight would be lost and these losses of dry weight continued during growing period to be $39 \%$ after twelfth growing day old.

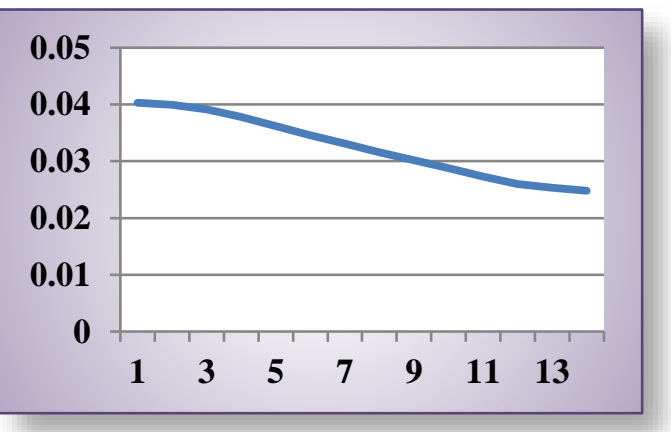

Fig. 2. Dry seedling weight (gm)

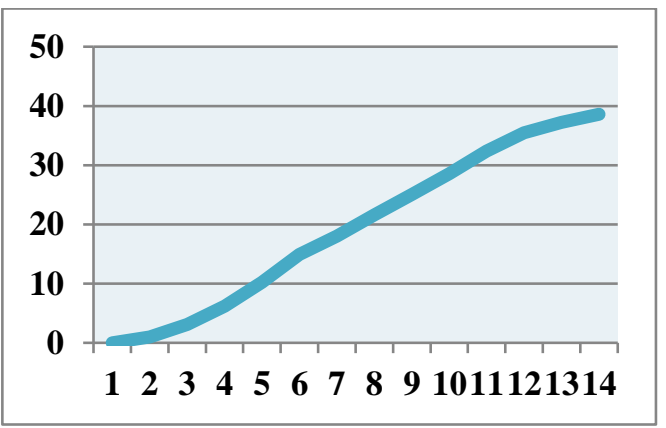

Fig. 3. \% loss of dry matter

Decrement in dry weight may be due to that soaking and germination processes caused leakage of storage materials of seeds and no dry substance would be built. These results agreed with Morgan et al (1992) who showed that during soaking and germination, seeds lose dry matter as they use their own energy reserves for growth in the short growing cycle. There is most commonly a DM loss ranging from $7 \%$ to $47 \%$ and suggested that photosynthesis is not important for the metabolism of the seedlings until the end of day 5.When the chloroplasts are activated, light did not have a significant effect on DM content and losses continued to increase from a value of $5.2 \%$ after 3 days to $12.3 \%$ after 6 days, probably reflecting the losses due to respiration and negligible amount of photosynthesis by young seedlings at the low light intensity (800 lux). 


\section{Effect of sowing location, cutting and their interaction on protein content of wheatgrass juice residues}

As affecting of growing location, higher content of protein of this factor was found in wheat grass's residues produced at open field condition (Table 3 ) however, low residues weight $(4.3 \mathrm{~kg})$ can provide one kilogram of protein content compared with laboratory condition $(4.6 \mathrm{~kg})$ on a dry weight basis. The influence of cutting on protein content was proved unequivocally. Dry residues collected from second cut were 259 gof protein while it was $204 \mathrm{~g}$ at first cut on a dry weight basis. Thus, big amount of residues were needed $(4.9 \mathrm{~kg})$ to obtained one kilo gram of protein at first cut compared with second cut $(3.9 \mathrm{~kg})$. For about the interaction of growing location and number of cutting, data were in favor of residues collected from squeezed grass grown in open field at second cut which had the highest protein content over others and an opposite quantity of residues content.

4. Effect of growing locations and number of cutting on protein and chlorophyll contents of wheatgrass juice

Table (4) revealed the contents of protein and chlorophyll of wheatgrass juice grown under laboratory and open field conditions at first and second cut.

Grown wheatgrass in laboratory improve protein content of its juice either at first or second cut than open field condition. However, wheatgrass juice at second cut under laboratory condition contained higher protein content $(3.39 \mathrm{~g} / 100 \mathrm{ml})$ compared with first cut $(3.03 \mathrm{~g} / 100 \mathrm{ml})$. Conversely, on open field, grass juice at first cut contained high protein content $(2.62 \mathrm{~g})$ over second cut $(2.01 \mathrm{~g})$. These results encouraged the consumption of wheatgrass juice for its protein content under laboratory and open field preferably at laboratory for its high protein content and the raw materials are cheap and available throughout the year and saving the land for producing strategically crops.

Plant based food and food products are the major source of nutrients such as proteins and chlorophyll, one of such main source is wheatgrass and its juice which is consumed for healthy growth of human body (Ashish et al 2012). Concerning storage proteins in wheat grains, Glutens play significant role in technological and nutraceutical of cereal grains. However, the gluten fraction was reported to be responsible for celiac disease and later on food allergy (Larre et al 2011).on the other hand, Michalcova et al (2012) showed that remarkable degradation of glutens started after three days and the lowest concentration was measured at the seventh day of germination of wheat grain. Therefore, wheatgrass juice can be recommended for celiac diseases patients to replace wheat bread nutrients and phytochemicals (need more research).

Influence of growing location and number of cutting were also affected the content of chlorophyll of wheatgrass juice (Table 4). Maximum chlorophyll content was determined from wheatgrass juice at second cut under open field condition $(0.466 \mathrm{mg} / \mathrm{ml})$. On the other hand, wheatgrass juice contained $0.424 \mathrm{mg}$ of chlorophyll at first cut as grown on open field which it was the highest value in compare with laboratory condition either at first cut $(0.223 \mathrm{ml})$ or second cut $(0.138 \mathrm{ml})$. Wheatgrass juice is one of the best sources of chlorophyll and most of its health benefits are attributed to this chlorophyll, besides other vital nutrients (Mogra and Rathi, 2013). The high chlorophyll content under open field condition related to direct sunlight effect along growth period (10 days old) compare with laboratory (8 sprouting days old under indirect sunlight). On the other hand, grown in soils and consumed raw, contamination with bacteria or other substances may be a concern women who are pregnant or breast- feeding should not use wheatgrass (Mogra and Rathi, 2013). Therefore, growing in laboratory using sterilized rice straw medium can be recommended in this study.

Reference mean daily requirement of protein intake was $56 \mathrm{mg} /$ day for male, $46 \mathrm{mg} /$ day for female and $19 \mathrm{mg} /$ day for children (DRI, 2002). Table (4) revealed that $100 \mathrm{ml}$ of fresh wheatgrass juice under laboratory condition can supply about $5.4,6.6$ and $16 \%$ at first cut and 6.1, 7.4 and $17.8 \%$ at second cut for male, female and children, respectively, which be higher than the open field juice supply. Higher intake of protein was reported in children followed by females and males.

Finally, an idea could be implemented in future to introduce wheatgrass juice as a health drink.

5. Effect of growing locations and number of cutting on minerals content of wheatgrass juice

Table (5) represents the contents of $\mathrm{Ca}, \mathrm{Fe}$, $\mathrm{Mg}, \mathrm{Zn}$ and Se of wheatgrass juice after first and second cut under laboratory and open field condition. The content of $\mathrm{Ca}$ of wheatgrass juice at second cut was found to be higher than that in the 
Table 3. Effect of growing location, cutting and their interaction on protein content $(\mathrm{kg})$ of wheatgrass juice residues

\begin{tabular}{|c|c|c|c|c|}
\hline \multicolumn{2}{|c|}{ Characters } & \multirow{2}{*}{$\begin{array}{c}\text { Residues dry } \\
\text { weight(g)/kg of } \\
\text { protein }\end{array}$} & \multirow{2}{*}{$\begin{array}{l}\text { Protein }(\mathrm{g}) / \mathrm{kg} \text { of } \\
\text { residues dry } \\
\text { weight }\end{array}$} & \multirow[b]{2}{*}{$\%$ Protein } \\
\hline Location (I) & Cutting (c) & & & \\
\hline \multirow{2}{*}{ Laboratory } & First cut & 4975 & 201 & 20.1 \\
\hline & Second cut & 4132 & 242 & 24.2 \\
\hline \multirow{4}{*}{ Open field } & Mean & 4554 & 222 & 22.2 \\
\hline & First cut & 4866 & 206 & 20.6 \\
\hline & Second cut & 3623 & 276 & 27.6 \\
\hline & Mean & 4245 & 241 & 24.1 \\
\hline \multirow{2}{*}{ Mean } & First cut & 4921 & 204 & 20.4 \\
\hline & Second cut & 3878 & 259 & 25.9 \\
\hline \multirow{3}{*}{ L.S.D (0.05) } & $\mathbf{L}$ & 0.8593 & 0.384 & \\
\hline & C & 0.8593 & 0.384 & \\
\hline & $L \times C$ & 1.2153 & 0.543 & \\
\hline
\end{tabular}

Table 4. Effect of growing locations and number of cutting on protein and chlorophyll contents of wheatgrass juice

\begin{tabular}{|c|c|c|c|c|c|c|}
\hline \multirow{3}{*}{ Location } & \multirow{3}{*}{ Cutting } & \multirow{3}{*}{$\begin{array}{l}\text { Chlorophyll } \\
\text { (mg/ml) }\end{array}$} & \multicolumn{4}{|c|}{ Protein } \\
\hline & & & \multirow{2}{*}{$\mathrm{g} / 100 \mathrm{ml}$} & \multicolumn{3}{|c|}{$\%$ DRI of $100 \mathrm{ml}$ of grass juice } \\
\hline & & & & Male & Female & Children \\
\hline \multirow[t]{2}{*}{ Laboratory } & First cut & 0.223 & 3.03 & 5.41 & 6.59 & 15.95 \\
\hline & Second cut & 0.138 & 3.39 & 6.05 & 7.37 & 17.84 \\
\hline \multirow[t]{2}{*}{ Open field } & First cut & 0.424 & 2.62 & 4.68 & 5.70 & 13.79 \\
\hline & Second cut & 0.466 & 2.01 & 3.60 & 4.38 & 10.60 \\
\hline
\end{tabular}

Table 5. Effect of growing locations and number of cutting on Minerals content ( $\mathrm{mg} / \mathrm{l})$ of wheatgrass juice

\begin{tabular}{|c|c|c|c|c|c|c|c|c|}
\hline \multirow{3}{*}{ Minerals } & \multicolumn{4}{|c|}{ Laboratory } & \multicolumn{4}{|c|}{ Open field } \\
\hline & \multirow[t]{2}{*}{$\mathrm{mg} / \mathrm{l}$} & \multicolumn{3}{|c|}{$\%$ DRI of $100 \mathrm{ml}$ of juice } & \multirow[t]{2}{*}{$\mathrm{mg} / \mathrm{l}$} & \multicolumn{3}{|c|}{$\%$ DRI of $100 \mathrm{ml}$ of juice } \\
\hline & & Male & Female & Children & & Male & Female & Children \\
\hline \multicolumn{9}{|c|}{ First cut } \\
\hline Calcium & 200 & 2 & 2 & 2 & 500 & 5 & 5 & 5 \\
\hline Ferric & 63.6 & 80 & 35 & 64 & 44.96 & 56 & 25 & 45 \\
\hline Magnesium & 2252 & 56 & 73 & 173 & 1089 & 27 & 35 & 84 \\
\hline Zinc & 8.81 & 8 & 11 & 18 & 5.28 & 5 & 7 & 11 \\
\hline Selenium & 0.0074 & 1.3 & 1.3 & 2.5 & 0.016 & 2.9 & 2.9 & 5.3 \\
\hline \multicolumn{9}{|c|}{ Second cut } \\
\hline Calcium & 300 & 3 & 3 & 3 & 7500 & 75 & 75 & 75 \\
\hline Ferric & 44.10 & 55 & 25 & 44 & 133.9 & 167 & 74 & 134 \\
\hline Magnesium & 398 & 10 & 13 & 31 & 1186 & 30 & 38 & 91 \\
\hline Zinc & 7.55 & 7 & 9 & 15 & 11.9 & 11 & 15 & 24 \\
\hline Selenium & ND & - & - & - & ND & - & - & - \\
\hline
\end{tabular}


first cut. On the other hand, grown wheatgrass on open field caused an increase on its content of $\mathrm{Ca}$ over laboratory either first or second cut. Highest Fe content was observed under field condition after second cut $(133.9 \mathrm{mg} / \mathrm{l})$ followed by first cut under laboratory $(63.6 \mathrm{mg} / \mathrm{l})$. Fe concentration of juice from first cut (field) and second cut (laboratory) were found to be almost constant around 44.0 $\mathrm{mg} / \mathrm{l}$. Lap tap water analysis for minerals content was 33.8 and 12.8 ppm for $\mathrm{Ca}$ and $\mathrm{Mg}$, respectively while Fe was not detected (Anwar et al 2009). The wheatgrass juice contained $2252 \mathrm{mg}$ per liter of $\mathrm{Mg}$ at first cut under laboratory condition which be higher than those contents at first and second cut under open field condition (1089 and $1186 \mathrm{mg}$, respectively) and second cut under laboratory (398 $\mathrm{mg} / \mathrm{l}$ ) (Table 5). Maximum and lower content of $\mathrm{Zn}$ was recorded at second and first cut under open field (11.9 and $5.28 \mathrm{mg} / \mathrm{l}$, respectively) (Table 5). Wheatgrass juice contained $16 \mathrm{mg} / \mathrm{l}$ of $\mathrm{Se}$ if grass were produced under open field at first cut where as it was $7.4 \mathrm{mg}$ under laboratory condition in the same first cut. Moreover, no Selenium content was detected in the juice obtained from second cut either under laboratory or open field condition (Table 5).

Previous data can revealed that growing wheatgrass under open field especially at second cut caused an increase in most of minerals juice content and these results can be explained to the higher chlorophyll juice content under open field condition at second cut (Table 4). Chlorophyll can be extracted from many plants, but wheatgrass is superior because it has been found to have over 100 elements needed by man. If grown in organic soil. It absorbs 92 of the known 102 minerals from the soil. Wheatgrass contains over 90 minerals, including high concentrations of the most alkaline minerals: potassium, calcium and magnesium. Consumption of $100 \mathrm{ml}$ of fresh wheatgrass juice under laboratory at first cut supply about $2 \%$ of daily intake of calcium while it was $5 \%$ under open field condition at the same cut(Table 5) and this percentage rose at the second cut to be $75 \%$ of the daily intake. Dietary Recommended Intakes (DRI) of iron was $8.0 \mathrm{mg}$ for male, $18 \mathrm{mg}$ for female and $10 \mathrm{mg} /$ day for children (DRI, 2004). As high recommended iron intake for female compare with male and children, grass juice can supply only about $35 \%$ and $25 \%$ of iron at first cut under laboratory and open field, respectively compared with $80 \%, 56 \%$ and $64 \%, 45 \%$ for male and children under laboratory and open field, respectively.
Same trend would be finding at the second cut to be $25 \%$ and $75 \%$ for female compared with $55 \%$, $167 \%$ and $44 \%$, $134 \%$ for male and children under laboratory and open field, respectively. Cereals exhibit inhibition of dietary iron absorption due to the endogenous phytate contained in their outer coats. Removal of the phytate in bran by different methods such as fermentation, germination and baking increases iron absorption by approximately 3.5 times (Hallberg et al 1986). At first cut, $100 \mathrm{ml}$ of juice can supply 56,73 and $173 \%$ of $\mathrm{Mg}$; however, it was 27, 35 and $84 \%$ under open field for male children, respectively. Conversely, at second cut, grass juice supply about only 10,13 and $31 \%$ under laboratory condition while it was 30,38 and $91 \%$ of $\mathrm{Mg}$ under open field for male, female and children, respectively. Grass juice also can supply about 5 to $18 \%$ of $\mathrm{Zn}$ at first cut and 7 to $24 \%$ at second cut. Regarding selenium DRI data in Table (5) showed that grass juice under laboratory at first cut will covered $1.3 \%, 1.3 \%$ and $2.5 \%$ while it was $2.9 \%, 2.9 \%$ and $6.3 \%$ under open field at the same cut for male, female and children, respectively. Yoshida et al (2007) showed that the availability of selenium in the radish sprout ranged between 33 and $65 \%$.When the amount of selenium was increased to $2 \mu \mathrm{g} / \mathrm{g}$ both the selenite form and selenium taken in with the radish sprout prevented the tumour cells from growing. Hama et al (2008) examined that Japanese radish sprout on the oxidative stress of female rats, the selenium diet of $12.5 \mathrm{mg} / \mathrm{kg}$ reduced the increase of the body mass but increased the mass of the liver. $30 \mathrm{ml}$ of freshly squeezed wheatgrass juice is equivalent in nutritional value to $1 \mathrm{~kg}$ of leafy green vegetables. Wheatgrass has quickly become "the new age espresso" offered in smoothies and juices, salads and even in tablets and powders and is one of the cereal grasses mostly used as a health drink (BenArye et al 2002).

\section{Effect of growing locations and number of cutting on the composition of amino acids of wheatgrass juice}

The compositions of amino acids were expressed in terms of $100 \mathrm{~g}$ proteins ( $16 \mathrm{~g} \mathrm{~N}$ ) (Table 6). In present work, the amino acid contents of wheat juice were differed slightly among laboratory and open field conditions. Aspartic acid recorded the highest concentration of amino acids of juice under laboratory condition either at first or second cut On the other hand, the first cut under open field 
Table 6. Effect of growing locations and number of cutting on the composition of amino acids of wheatgrass juice per $16 \mathrm{~g}$ of $\mathrm{N}$

\begin{tabular}{|c|c|c|c|c|}
\hline \multirow{2}{*}{$\begin{array}{c}\text { Sowing locations } \\
\text { Cutting }\end{array}$} & \multicolumn{2}{|c|}{ Laboratory } & \multicolumn{2}{|c|}{ Open field } \\
\hline & First cut & Second cut & First cut & Second cut \\
\hline \multicolumn{5}{|c|}{ Non essential amino acids } \\
\hline Aspartic acid & 16.50 & 18.29 & 10.69 & 11.94 \\
\hline Alanine & 4.95 & 3.24 & 6.87 & 5.97 \\
\hline Glutamic acid & 8.91 & 5.60 & 12.21 & 10.45 \\
\hline Serine & 3.63 & 2.65 & 4.58 & 3.98 \\
\hline Total & 33.99 & 29.78 & 34.35 & 32.34 \\
\hline \multicolumn{5}{|c|}{ Conditionally essential amino acids } \\
\hline Argenine & 5.28 & 3.24 & 6.87 & 5.97 \\
\hline Proline & 3.63 & 2.06 & 4.20 & 4.48 \\
\hline Glycine & 3.96 & 2.36 & 6.11 & 4.98 \\
\hline Cysteine & 0.99 & 1.18 & 1.15 & 1.49 \\
\hline Tyrosine & 0.99 & 1.77 & 1.91 & 2.49 \\
\hline Total & 14.85 & 10.61 & 20.24 & 19.41 \\
\hline \multicolumn{5}{|l|}{ Essential amino acids } \\
\hline Isoleucine & 3.63 & 2.36 & 4.58 & 4.48 \\
\hline Therionine & 3.96 & 2.36 & 3.44 & 4.48 \\
\hline Valine & 4.62 & 3.24 & 6.11 & 5.47 \\
\hline Phenylalanine & 4.29 & 2.95 & 5.34 & 5.47 \\
\hline Lysine & 5.61 & 3.83 & 6.49 & 6.47 \\
\hline Leucine & 6.27 & 3.54 & 9.16 & 7.96 \\
\hline Methionine & 1.32 & 0.59 & 1.53 & 1.99 \\
\hline Histidine & 2.31 & 2.65 & 3.05 & 2.49 \\
\hline Total & 32.01 & 21.52 & 39.70 & 38.81 \\
\hline
\end{tabular}

or laboratory condition increased the essential amino acids as compared with second cut and the data was more pronounced with lysine and leucine amino acids. However, Glutamic, Alanine and Serine were the highest non essential amino acids in first cut in both open field and laboratory conditions. Similar increment in first cut in both open field and laboratory were observed for two conditionally amino acids Arganine and Glycine (Table 6). Chavan and Kadam (1989) stated that an increase in proteolytic activity during sprouting is desirable for nutritional improvement of cereals because it leads to hydrolysis of prolamins and the liberated amino acids such as glutamic and proline are converted to limiting amino acids such as lysine. Lysine is an essential amino acid; diets deficient in lysine can impair growth in children and reduce immune function.

Usual doses of lysine supplementation range from 0.5 to $4.0 \mathrm{~g} /$ day. Lysine and arginine share a common transport system for intestinal absorption and uptake into cells of the body and brain. Be- cause arginine competes for uptake with lysine, a high ratio of lysine/arginine in the diet enhance the effects of lysine supplementation (Zimmermann, 2001). However, differences in the amino acids content per $16 \mathrm{~g} \mathrm{~N}$ can revealed that (1) most of amino acids of juice were increased if grass are grown under open field over laboratory either at first or second cut. (2) Grass juice at first cut was succeeded high amino acids content in compare with second cut especially in essential amino acids.

\section{Effect of growing locations on the percent- age of natural phytochemicals of wheat seeds and wheatgrass juice}

Wheat seeds showed a predominance of saturated aliphatic alkanes Nonacosane $(21.1 \%)$, Triacontane (19.9\%), Tetratriacontane (18.9\%), Heneicosane $(12.8 \%)$ and Docosane $(12.3 \%)$. As it can be seen from Table (7), it is clearly visible that sprouting had evidence influenced on wheat seeds 
Table 7. Effect of growing locations on the percentage of phytochemicals of wheat seeds and wheatgrass juice

\begin{tabular}{|lccc|}
\hline Percentage of phytochemicals & $\begin{array}{c}\text { Dry wheat } \\
\text { seeds }\end{array}$ & $\begin{array}{c}\text { Laboratory } \\
\text { grass juice }\end{array}$ & $\begin{array}{c}\text { Open field } \\
\text { grass juice }\end{array}$ \\
\hline Eicosane & 0.76 & 0.66 & 0.70 \\
Tetracosane & 4.96 & 3.66 & 4.37 \\
Heneicosane & 12.78 & 11.06 & 11.68 \\
Triacontane & 19.90 & 18.63 & 19.52 \\
1,3-Dioctadecyloxypropane & 0.28 & - & - \\
Nonacosane & 21.09 & 20.22 & 21.50 \\
2-Methyldocosane & 0.63 & 0.40 & 0.40 \\
Tetratriacontane & 18.91 & 17.89 & 17.16 \\
3-Ethyl-5-(2'-ethylbutyl)octadecane & 0.59 & 0.58 & 0.38 \\
1-[1-Methyl-2-(octadecyloxy)ethoxy]octadecane & 0.39 & 0.23 & 0.37 \\
Docosane & 12.31 & 11.27 & 10.29 \\
Hexadecanoic acid,2(octadecyloxy)ethyl ester & 0.66 & - & - \\
3-Methylheneicosane & 0.41 & - & - \\
Octacosane & 6.33 & 5.06 & 4.51 \\
Arachic acid & - & 1.89 & 0.44 \\
2,6-Di-tert-butylhydroquinone & - & 0.84 & 0.01 \\
Tritetracontane & - & 3.15 & - \\
3,7,11,15-Tetramethyl-2-hexadecen-10l & - & 2.07 & 0.41 \\
Methyl 5,11,14-eicosatrienoate & - & 0.18 & 0.33 \\
Stearic acid, 2-(octadecyloxy) ethyl ester & - & 2.21 & 2.97 \\
Squalane & - & - & 4.96 \\
\hline
\end{tabular}

natural phytochemical constituents. 1, 3Dioctadecyloxypropane, 3-Methylheneicosane and the fatty ester Hexadecanoic acid, 2(octadecyloxy) ethyl ester were recorded $0.28 \%, 0.66 \%$ and $0.41 \%$, respectively in seeds, however, it is not detected or may be traces in wheatgrass juice.

Alkans play a role, if a minor role, in the biology of the three eukaryotic groups of organisms: fungi, plants and animals (Hendey, 1964), they protect the plant against water loss, prevent the leaching of important minerals by the rain, and protect against bacteria, fungi, and harmful insects (Baker, 1982). The higher melting point of these alkanes can cause problems at low temperature and in Polar Regions. In latter function they work at the same time as anti-corrosive agents, many solid alkanes find use as paraffine wax. Nonacosane is a straight-chain hydrocarbon with a molecular of $\mathrm{C}_{29} \mathrm{H}_{60}$, and evidence suggests it plays a role in the chemical communication of several insects (Beri et al 2004) Nonacosane has also been identified within several essential oils. It can also be prepared synthetically (Bentley et al 1955). Conversely, Arachic acid, Stearic acid, 2(octadecyloxy) ethyl ester, Tritetracontane, 2,6-Di- tert-butylhydroquinone, 3,7,11,15-Tetramethyl-2hexadecen-1ol and Methyl 5,11,14-eicosatrienoate were found at wheatgrass juice either under laboratory or open field conditions while it is not presence (or traces) in wheat seeds(Table 7). On the other hand, Squalane was absence in laboratory grass juice while it was $4.96 \%$ of total phytochemical constituents in open field grass juice.2,6-Di-tertbutylhydroquinone is a highly effective antioxidant (Richard, 2008). In foods, it is used as a preservative for unsaturated vegetable oils and many edible animal fats (Almeida et al 2011). It does not cause discoloration even in the presence of iron, and does not change flavor or odor of the material to which it is added (Richard, 2008). It can be combined with other preservatives such as butylatedhydroxyanisole (BHA). It is added to a wide range of foods, with the highest limit $(1 \mathrm{~g} / \mathrm{kg})$ permitted for frozen fish and fish products. Its primary advantage is enhancing storage life. Squalane is a hydrocarbon and triterpene derived by hydrogenation of squalene, most notably in the livers of sharks (Allison, 1999). Squalane has low acute toxicity and is not an irritant at the concentrations used in cosmetics. 


\section{REFERENCE}

Abdallah, M.M.F. 2008. Seed sprouts, a pharaoh's heritage to improve food quality. Arab Universities journal of Agricultural Sciences. 16(2): 469-478.

Abdallah, M.M.F., Mahrous, N.M., Thanaa. F. Mohammadi and Mona, A. Abdel-Aziz. 2014. A new source of fresh green feed barley sprouts grown on wheat or rice straw medium. Journal of Environmental Science. (In Press).

Allison, Anthony, C. 1999. Squalene and Sqalane emulsions as adjuvants. Methods. 19(1), 8793.

Almeida, E.S., Almeida Eduardo, S., Portela Flaysner, M., Sousa Raquel, M.F., Daniel. Daniela, Terrones Manuel, G.H., Richter Eduardoand, M., Muñoz Rodrigo, A.A. 2011. Behaviour of the antioxidant tertbutylhydroquinone on the storage stability and corrosive character of biodiesel. Fuel 90(11): 3480-3484.

Anwar, Dina. A., Hifnawy, M.S., Kandeel, A.M. and Abdallah, M.M.F. 2009. Nutritional and health-related constituents of fenugreek, sunflower, mustard sprouts as a functional food. 54(1):175-189.

AOAC. 2012a. Official Methods of Analysis of AOAC International. $19^{\text {th }}$ ed. Dumes method. No. 968.06. Chapter 4, pp. 25-26.

AOAC. 2012b. Official Methods of Analysis of AOAC International. $19^{\text {th }}$ ed. No. 994.12. Chapter 4, pp. 9-13.

AOAC. 2012c. Official Methods of Analysis. 19th ed. No. 968.08. chapter 4, p. 56.

Ashish, S., Shilpa, K., Raghav Singh, R., Sanjay, K. and Rajendran, N. 2012. Wheatgrass: an alternative household nutritional food security. International Research J. Pharmacy. 3(7): 246-250.

Baker, E.A. 1982. Chemistry and morphology of plant eqicuticularwaxs.In "The Plant Cuticle". Academic Press, London. pp. 139-165.

Ben-Arye, E., Goldin, E., Wengrower, D., Stamper, A., Kohn, R. and Berry, E. 2002. Wheatgrass juice in the treatment of active distal ulcerative colitis: A randomized double-blind placebo-controlled trial. Scandinavian J. Gastroenterology. 7(4): 444-449.

Bentley, H.R., Henry, J.A., Irvine, D.S., Mukerji D. and Spring, F.S. 1955. Triterpenoids. Partxxxll. Cyclolaudenol, a triterpenoid alcohol from opium. J. Chem. Soc. pp. 596-602.
Beri, B., Gerade, J.D. and Clark, J.M. 2004. Relative abundance of two cuticular hydrocarbons indicates whether a mosquito is old enough to transmit malaria parasites. J. Med. Entomol. 41(4): 807-809.

Chavan, J. and Kadam, S.S. 1989. Nutritional improvement of cereals by sprouting. Critical Reviews in Food Science and Nutrition. 28(5): 401-437.

Chung, T., Nwokolo, E.N. and Sim, J.S. 1989. Compositional and digestibility changes in sprouted barley and canola seeds. Plant Foods for Human Nutrition. 39: 267-278.

DRI. 2002. Dietary Reference Intakes for Individuals, Macronutrients. Food and Nutrition Board, Institute of Medicine, National Academies. Available at http://www.nap.edu.

DRI. 2004. Dietary Reference Intakes for Individuals, Elements and Vitamins. Food and Nutrition Board, Institute of Medicine, National Academies. Available at http://www.nap.edu

Falcioni, G., Calzuola, L.M., Marsili, V. and Gianfranceschi, G. 2002. Antioxidant activity of wheat sprout extracts in Vito: inhibition of DNA oxidative damage. Journal of Food Science. 67: 2918-2922.

Hallberg, L., Brune, M. and Rossander, L. 1986. Effect of ascorbic acid on iron absorption from different types of meals. Human Nutrition Applied Nutrition. 40A: 97-113.

Hama, H., Jamanoshita, O., Chiba, M., Takeda, I. and Nakajima, T. 2008. Selenium-enriched japanese radish sprouts influence glutathione peroxidase and glutathione S- transferase in an organ - specific manner in rate. Journal of Occupational Health. 50: 147-154.

Hendey, N.I. 1964. Some observations on Cladosporiumresinae as a fuel contaminant and its possible role in the corrosion of aluminium alloy fuel tanks. Transactions of the British Mycological Society. 47(7): 467-475.

Larre, C., Lupi, R., Gombaud, G., Brossard, C., Branlard, G., Moneret-Vautrin, D.A., Rogniaux, H. and Denery-Papini, S. 2011. Assesment of allergenicity of diploid and hexaploid wheat genotypes: Identification of allergens in the albumin globulin fraction. In. Journal of Proteomics. 74: 1279-1289.

Lichenthaler, H.K. and Wellburn, A.R. 1983. Determinations of total carotenoids and Chlorophyll $a$ and $b$ of leaf extracts in different solvents. Biochem. Soc. Trans., 11(5): 591-592. 
Michalcova, Eva.; Elena. Potocka; Daniela. Chmelova and Miroslav. Ondrejovic. 2012. Study of wheat protein degradation during germination. Journal of Microbiology, Biotechnology and Food Sciences. 1(6): 14391447.

Mogra, R. and Rathi, P.. 2013. Health benefits of wheatgrass- a wonder food. International Journal of Food and Nutritional Sciences. 2: 10-13.

Mohammadi, Thanaa. F. and Abdallah, M.M.F. 2007. Effect of four seed sprouts on rice straw and spent mushroom media of rice straw to be used as a green fodder. Egyptian J. Nutrition and Feeds. 10(2): 679-691.

Moongngarm, A. and Saetung, N. 2010. Studies on comparison of chemical compositions and bioactive compounds of germinated rough rice and brown rice Thailand. Food Chemistry. 122: 782-788.

Morgan, J., Hunter, R.R. and O'Haire, R. 1992. Limiting factors in hydroponic barley grass production. $8^{\text {th }}$ International Congress on Soilless Culture. Hunter's Rest, South Africa. pp. 241261.

Mujoriya, R. and BabuBodla, R. 2011. A study on wheat grass and its nutritional value. Food Science and Quality Management 2: 1-8.

Richard D. O'Brien. 2008. Fats and oils. Formulating and processing for applications. $3^{\text {rd }}$ ed. Eagan press handbook, London. 168 p.
Sangronis, E., Rodriguez, M., Cava, R. and Torres, A. 2006. Protein quality of germinated Phaseolus vulgaris. European Food Research and Technology. 222(1): 144-148.

Santana, Patricia. Manzano; Migdalia. Miranda; Juan. Abreu. Payrol; Mario. Silva; Victor. Hernandez and Esther. Peralta. 2013. Gas Chromatography-Mass Spectrometry study from the leaves fractions obtained of Vernonanthura Patens (Kunth) H. Rob. International Journal of organic chemistry 3:105109.

Singh, N., Verma, P. and Pandey, B.R. 2012. Therapeutic potential of organic Triticumaestivum Linn. (wheatgrass) in prevention and treatment of chronic diseases: An overview. International J. of Pharmaceutical Scinces and Drug Research. 4(1): 10-14.

Snedecor, G.W. and Cochran, W.G. 1980. Statistical methods $7^{\text {th }}$ ed., lowa State Univ. Press, Ames lowa, USA.

Yoshida, M., Okada, T., Namikawa, Y., Matsuzaki, Y., Nishiyama, T. and Fukungaga, K. 2007. Evaluation of nutritional availability and anti - tumor activity of selenium contained in selenium - enriched kaiware radish sprouts. Biosci. Biotechnol. Biochem., 71: 2198 2205.

Zimmermann, M. 2001. Burgerstein's Handbook of Nutrition: Micronutrients in the prevention and therapy of disease. $4^{\text {th }}$ ed. Thieme New York. pp. 22-57. 